[Vol. 129:1516;

\title{
DISCUSSION
}

\section{PASSING ON THE MONOPOLY OVERGHARGE: THE WELFARE IMPLICATIONS}

\author{
Philip A. Viton † and Clifford M. Winston
}

In an Article published recently in this Review, 1 Professors Robert Harris and Lawrence Sullivan provide a sustained and effective rebuttal to certain questions of economic theory and evidence that disturbed the United States Supreme Court in Illinois Brick Co. v. Illinois. ${ }^{2}$ In that case, the Court prevented the ultimate consumer of a good, whose production ${ }^{3}$ at some stage before the final sale is subject to an exercise of market power, from obtaining antitrust redress against the exerciser of that power. Contrary to the view of the Court, however, Harris and Sullivan argue that (1) it is possible, 4 and not exorbitantly difficult or costly, ${ }^{5}$ to identify the extent to which a "monopoly overcharge" will be passed on in subsequent stages of production; (2) it is likely, given our knowledge of United States industrial structure, that this extent is very high, ${ }^{6}$ and (3) if a stage of production exercising the market power were successfully sued by the next stage, any antitrust damages recovered would be a lump-sum windfall and not necessarily "passed back" to the consumers in the form of lower prices. ${ }^{7}$ Hence, in Harris

† Assistant Professor of Regional Science and of Transportation, University of Pennsylvania. A.B. 1972, Brown University; Ph.D. 1977, University of California, Berkeley.

If Assistant Professor, Center for Transportation Studies, Massachusetts Institute of Technology. A.B. 1974, University of California, Berkeley; M.Sc. 1975, London School of Economics; Ph.D. 1979, University of California, Berkeley.

1 Harris \& Sullivan, Passing on the Monopoly Overcharge: A Comprehensive Policy Analysis, 128 U. PA. L. REv. 269 (1979).

2431 U.S. 720 ( 1977 ).

3 To restrict the number of technical terms, we use the word "production" to signify either production or distribution.

4 Harris \& Sullivan, supra note 1, at 275-99, 315-21

5 Id. 321-38.

Id. 290-94, 321-38. Curiously, Harris and Sullivan argue that the rate of passing on might even exceed $100 \%$ in certain instances. Id. 303-09. One might doubt whether, in a case in which a stage of production is subject to an overcharge of one dollar and then "passes on" an overcharge of two dollars, the correct way to describe it is "passing on."

$\tau$ Id. 298-99. 
and Sullivan's view, the ruling of the Court in Illinois Brick represents an almost certain reduction of consumer welfare. ${ }^{8}$

These conclusions, among other matters, have been subsequently challenged by Professors William Landes and Richard Posner $^{9}$ and defended by Harris and Sullivan ${ }^{10}$ in a recent exchange in this Review. In our view, however, this discussion did not alter the validity of the original three claims made by Harris and Sullivan. This is hardly surprising because the analysis of the economics of passing-on ${ }^{11}$ is an uncontroversial application of taxincidence theory. On the other hand, the status of the welfare conclusion is less clear, and as formulated by Harris and Sullivan may indeed be wrong. ${ }^{12}$

The difficulty arises because Harris and Sullivan restrict their analysis to the case of a single chain of economic activity. ${ }^{13}$ This approach-known technically as "partial equilibrium analysis"-is perfectly valid when the unconsidered part of the economy is roughly ${ }^{14}$ competitive. In that situation, any exercise of market power leads to an unambiguous deadweight welfare loss to society. ${ }^{15}$

When the rest of the economy contains substantial noncompetitive sectors, however, the results change. Indeed, the following

8 It is interesting to ask whether the Court's decision in Illinois Brick is the result of the changing composition of the Supreme Court as Justice Douglas once charged. See United States v. General Dynamics Corp., 415 U.S. 486, 527 (1974) (Douglas, J, dissenting). For an analysis of the Court's antitrust decisions, and whether they depend on the political affliations of the individual Justices, see Viton, Deciding Antitrust Cases in the Supreme Court: Does Party Affiliation Matter? (1980) (unpublished article on file with the author).

9 Landes \& Posner, The Economics of Passing On: A Reply to Harris and Sullivan, 128 U. PA. L. REv. 1274 (1980).

10 Harris \& Sullivan, Passing on the Monopoly Overcharge: A Response to Landes and Posner, 128 U. PA. L. REv. 1280 (1980).

11 See, e.g., Harris \& Sullivan, supra note 1, at 275-99.

12 It should be clear that our focus here is with the desirability, as a matter of antitrust policy, of the implications of Harris and Sullivan's analysis. We take the view that the justification of antitrust, and indeed of any economic analysis relying on perfect competition as a standard, stems from the welfare properties of competitive equilibria. See generally R. Bork, Tre Antrmaust Paradox (1978). In the context of Harris and Sullivan's Article, our concern is with the policy implications of "passing-on" as well as with what they refer to as "compensatory justice." See, e.g., Harris \& Sullivan, supra note 1 , at 272,354 . As we show below, the appropriate compensations might be vastly different from those imagined by Harris and Sullivan; in addition, the identities of any parties to be compensated might also differ.

13 Harris \& Sullivan, supra note 1 , at 277.

14 See Arrow, The Organization of Economic Activity: Issues Pertinent to the Choice of Market Versus Nonmarket Allocation, in Subcomm. on Economy IN Government, Jodnt Economic Comen, 91st Cong., Ist Sess., The Analysis and Evaldation of Public Expenditures: The PPB Sxstem 47 (Joint Comm. Print 1969).

15 See, e.g., E. Mansfietd, Mrcroeconomas 268-70 (1970); Harris \& Sullivan, supra note 1, at 282 n.46. 
can be demonstrated: Consider an economy in which one sector is constrained to eschew marginal cost pricing. Examine also another sector that merely happens not to be competitive. Suppose we now require that this second sector behave competitively. Can we be sure of a welfare gain? The answer is that, in general, we cannot.16 When there is a residual noncompetitive sector, bringing the rest of the economy into competitive compliance may actually reduce welfare. ${ }^{17}$

To illustrate this point, consider an industrial chain that consists of a supplier of an input to a product, a manufacturer of the product who operates in a competitive output market, and consumers of that product. Let us say the relevant input is transportation; in particular, unregulated motor carrier service. Suppose that this service is priced above marginal cost; in addition, it is recognized that a close substitute, rail service, is constrained by regulation to maintain its prices above marginal cost. ${ }^{18}$ Finally, it is assumed for simplicity that the transportation inputs and the manufacturer's product are produced at constant marginal cost. Given the preceding assumptions, it is clear that the manufacturer will pass on the entire motor carrier overcharge to the consumers. ${ }^{19}$ Yet the Illinois Brick holding precludes the consumers from suing the motor carrier. Applying their general argument, Harris and Sullivan's conclusion in this situation would be that Illinois Brick should be overruled because the motor carrier's pricing behavior has led to a social welfare loss. ${ }^{20}$

Unfortunately, from the standpoint of economic efficiency, this conclusion might be incorrect. To demonstrate this, we will

16 See E. MANSFIELD, supra note 15, at 478; Lipsey \& Lancaster, The General Theory of the Second-Best, 24(1) Rev. Econ. Stud. 11 (1956).

17 This result can also be formulated as follows: When there is a residual noncompetitive sector, forcing a competitive sector to deviate from marginal cost pricing might actually increase welfare.

18 The analysis to be presented here does not depend on the fact that the substitute product (here, rail) is a regulated industry. Any uncorrectable exercise of market power (derived, for instance, from production technologies) will lead to the same result. The assumption of a regulated industry, however, does simplify the diagrammatic analysis.

19 An analogous example and result is presented by Harris \& Sullivan, supra note 1 , at 292.

20 Observe that the substitute product is not part of the particular chain of distribution of interest in classical passing-on analysis (which in this case is the chain of distribution for motor carrier services). That is, our analysis spotlights, in a much simplified manner, general equilibrium results as opposed to the partial equilibrium (single chain) analysis stressed by Harris and Sullivan. Whether the supply curve in the chain is horizontal, see id. 291 \& n.57, is irrelevant to our purposes here. 
analyze the welfare implications of the motor carrier's overcharge in the input market. ${ }^{21}$ The manufacturer's demand $(D)$ and the marginal costs (MC) and prices $(P)$ of motor carrier ( $t$ ) and rail $(r)$ service are shown in Figure 1. To simplify matters, it is assumed that the marginal costs and demands are the same for each service. Let us suppose that the motor carrier's initial price, $P_{t}^{\prime}$, is equal to marginal cost, but rail's price, $\mathrm{P}_{\mathrm{r}}^{\prime}$, is above marginal cost. The deadweight loss that results from the rail mark-up is given by area $A$ in the figure. If the motor carrier's price is then raised above marginal cost to $\mathrm{P}_{t}^{\prime \prime}$ (equal to $\mathrm{P}_{\mathrm{r}}^{\prime}$ ), we obtain the following result. First, given that rail and motor carrier services are substitutes, the demand for rail will shift to the right (to $D_{r}^{\prime}$ ) in response to the motor carrier's price increase. It should be noted that rail's price does not change (hence $D_{t}$ does not shift). The welfare gain associated with the increased demand for rail is represented by the areas $\mathrm{A}$ and $\mathrm{C}$ (the increased profits to the railroad), plus the area $D$, representing increased benefits to shippers. On the other hand, the welfare loss from the motor carrier's price increase is represented by area B. By construction, area $\mathrm{A}$ is equal to area $\mathrm{B}$. Hence, these offsetting effects cancel and we are left with a net welfare gain from the price increase equal to the areas $C$ plus $D .{ }^{22}$ In essence, although the motor carrier has initiated a mark-up that has contributed to an increase in allocative efficiency, it could be the defendant in a consumer suit ${ }^{23}$ if Harris and Sullivan's recommendation regarding Illinois Brick were followed. ${ }^{24}$ It should be clear, however, that from a social welfare perspective Harris and Sullivan might not be justified in encouraging such a suit. ${ }^{25}$

21 The welfare implications of the overcharge can be analyzed in either the input or output market. See Jacobsen, On the Equivalence of Input and Output Market Marshallian Surplus Measures, 69 AM. Econ. Rev. 423 (1979).

22 Recalling our earlier discussion, see note 12 supra, it is clear that any coherent notion of compensatory justice should recognize the benefits accruing in the other (here, rail) market.

23 Of course, under Illinois Brick, the motor carrier could be a defendant in a suit brought by a direct purchaser. In this sense, the Supreme Court's assumptions are as open to challenge as Harris and Sullivan's. But see note 25 infra.

24 When there is precisely one substitute, it can be shown that welfare must increase with the price set at $\mathrm{P}_{t}$ " because this is the optimal "second best price" given $\mathrm{P}_{\mathrm{r}}$. See Lipsey \& Lancaster, supra note 16, at 11-12.

25 Emphasis is placed on the word "might" because it is necessary that the gainers actually compensate the losers in order for an unambiguous improvement in social welfare to actually take place.

It is important to note that Harris and Sullivan, Landes and Posner, and the Supreme Court all accept the premise that the motor carrier should be subject to suit in this case. Even so, Harris and Sullivan argue that the net effect of overruling Illinois Brick would be an increase in the number of passing-on suits. See Harris \& Sullivan, supra note 1 , at 349-54. 


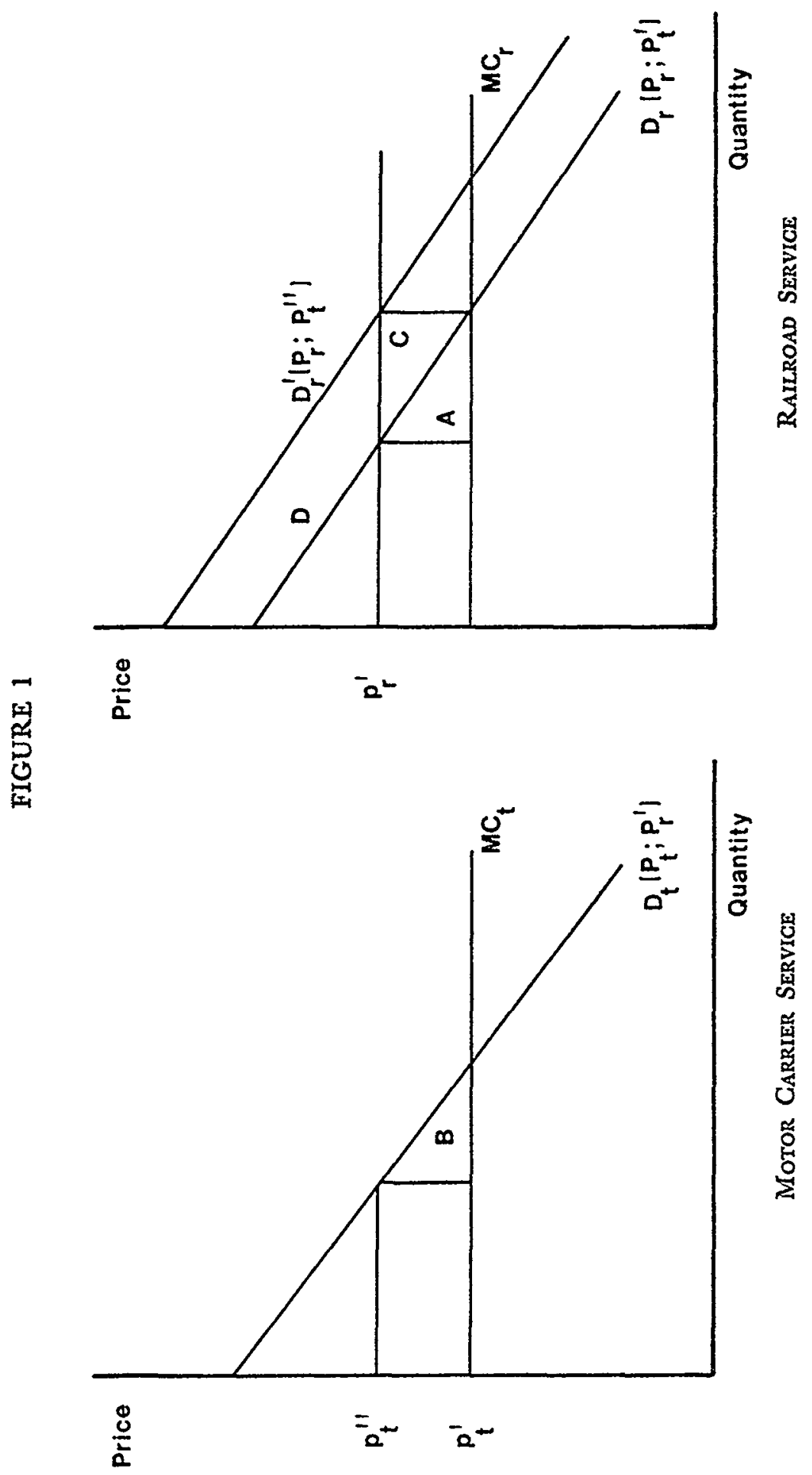


This is a disturbing result for antitrust analysis generally, and for the analysis of passing on in particular. It suggests that, even though the Supreme Court might have been wrong in its analysis of Illinois Brick (as Harris and Sullivan demonstrate), it might still prove to have been right as a matter of policy. It is not impossible that the market power exercised in passing-on cases serves to balance the welfare losses owing to the presence of noncompetitive sectors elsewhere in the economy.

It is, of course, an empirical question whether such sectors exist; but there is a substantial literature suggesting that they do. In particular, competition is generally unworkable in those industries subject to increasing returns to scale. Examples of industries of this sort include (or are often thought to include) telephone services, electric utilities, pipeline transportation, integrated auto production, typewriters, cement manufacturing, steel production, and possibly intercity air transportation. ${ }^{26}$ The relevant issue then becomes the extent to which non-marginal-cost pricing in these (and other similar) industries leads to a welfare gain associated with non-marginal-cost pricing in an industry under passing-on attack. To the extent that it does, then a policy of restricting the ability of consumers further down the chain to sue for treble damages (given that up-stream members are less likely to sue) ${ }^{27}$ might be the correct policy. ${ }^{28}$

Again, we emphasize that we have no empirical evidence that the result in Illinois Brick is correct. Indeed, the considerations

26 See, e.g., J. Barn, Indostriar Organization ch. 6 (1968) (automobiles, cement, and steel); A. Fruedlander, The Dinemama of Fretgrt Transport Reguration (1969) (pipelines); F. Scmerer, Industruad Market Structure and EcoNoma Performance ch. 4 (1970) (typewriters); Christensen \& Greene, Economics of Scale in U.S. Electrical Power Generation, 84 J. Por. Ecos. 655 (1976) (electrical utilities); Waverman, The Regulation of Intercity Telecommunications, in Promoting Competimion in Regulated Markets 201 (A. Phillips ed. 1975) (telephone services); Caves, Christensen \& Tretheway, Scale Economies in the U.S. Trunk Airline Industry (1980) (unpublished paper on file with the authors) (intercity air transportation).

\section{See note 21 supra.}

$28 \mathrm{It}$ is worth emphasizing that the analysis we envision is in principle no more difficult to carry out than that described by Harris and Sullivan. What is required is an examination of significant cross-elasticities of demand for a given product in order to identify relevant sectors in which irreducible market power might obtain. Estimation of cross-elasticities is in principle no more difficult than obtaining ownprice elasticities. Even though Harris and Sullivan appear to believe that results such as column 13 of their Appendix ("Probability of High Passing On," divided into four qualitative categories, see Harris \& Sullivan, supra note 1, at 355-60) can serve to delimit the required empirical work, we cannot believe that these results would be accepted as probative by any court, especially one concerned with monetary compensatory damages. It would therefore appear that detailed empirical work will always be required. 
adduced here may fall under Justice White's categorization of the "economist's hypothetical model." ${ }^{29}$ But it should at least give us pause before concluding too hastily that, as a matter of policy, the Supreme Court has been leading us down the garden chain.

29 Illinois Brick Co. v. Illinois, 431 U.S. at 732. 